\title{
Opening address: Powerful tool of persuasion or a waste of time?
}

\author{
Willem Gravett \\ BLC LLM LLD \\ Senior Lecturer in Procedural Law, University of Pretoria
}

\begin{abstract}
OPSOMMING
Die openingsrede: Kragtige instrument van oortuiging of 'n mors van tyd?
\end{abstract}

Dit sou ondenkbaar wees vir die meeste Amerikaanse verhoorprokureurs om afstand te doen van die openingsrede. Hulle glo dat die openingsrede 'n onvervangbare eerste geleentheid is om die kliënt se saak te bepleit. In teenstelling hiermee blyk die algemene praktyk in Suid-Afrika - veral in strafsake - te wees om af te sien van die openingsrede. Die persepsie is dat die openingsrede 'n "mors van tyd is" want, anders as Amerikaanse juries bestaande uit leke burgers, het ons ervare voorsittende beamptes wat al "alles gehoor het." Hierdie persepsie blyk gebaseer te wees op die veronderstelling dat die uitsluitlike funksie van die openingsrede is om "kortliks die feite uiteen te sit wat bewys gaan word." Die oogmerk van hierdie artikel is om advokaatskap in die openingsrede en navorsingsbevindinge op die gebiede van sosiale kognisie, boodskapbegrip en oortuiging te sintetiseer. Die doel is om aan te toon dat, buiten die tradisionele funksie daarvan, die openingsrede ook 'n kragtige instrument van oortuiging kan wees. Die tyd het aangebreek om die fiksie te verwerp dat voorsittende beamptes in staat is om geen opinies te vorm oor 'n saak totdat al die getuienis aangehoor is nie. Gegronde sielkundige teorie, gesteun deur algemene ervaring, dui daarop dat die openingsrede kan, tot ' $n$ beduidende mate, die voorsittende beampte se siening kan beïnvloed rakende die feite en die reg, en lei tot die skepping van 'n kragtige eerste indruk van die karakters in die saak. Dit kan blywende indrukke skep wat by die voorsittende beampte sal bly lank nadat die detail van die getuienis vergete is. Suid-Afrikaanse regslgeleerdes moet sosiale sielkundige navorsing aangryp en gebruik om die vaardigheid aan die kern van advokaatskap - hoe om effektief en eties te oorreed - te verfyn.

\section{Introduction}

There was an awkward moment on the first morning of the Oscar Pistorius trial. All preliminary procedural matters dispensed with the prosecutor declared the state ready to call its first witness. The judge, in a rather incredulous tone, asked: "Before you do that, there's no opening address?" The prosecutor, who clearly had not anticipated giving an opening address, responded: "Uh ... I will do so My Lady if the Court require[s] me to do that ... I will indeed do so." 1

1 The prosecutor then proceeded to deliver an opening address of approximately only 80 seconds, in which he emphasised the circumstantial nature of the state's evidence and the fact that there 
Most American trial lawyers, especially prosecutors, would find it unthinkable to waive the opening address. Generally, American trial lawyers believe that the fact-finder's first impressions "harden like cement", 2 thus making the opening address an invaluable tool of persuasion and an irreplaceable first opportunity to advocate the lawyers' case to the fact-finder. ${ }^{3}$

In contrast, in the main the practice in South Africa, especially in criminal trials, is to forego the opening address. ${ }^{4}$ The perception is that the opening address is a "waste of time", because, unlike the American system of juries of lay citizens, South Africa has experienced judges who have "heard it all". 5 This perception seems to be based on the understanding that the sole purpose of the opening address is to "briefly outline the facts intended to be proved". 6

With regard to the South African approach, Marnewick argues that the American (and British) fervour in respect of the persuasive power of the opening address relates to "jury trials", and that the Anglo-American view "should be tempered for the fact that judges are trained not to make up their minds before all the evidence has been led and argument has been heard"7

This opinion is emblematic of the perilous fiction under which some trial lawyers operate - that judges, as opposed to juries, somehow are

were no eye witnesses. The exchange between the prosecutor and Masipa J was transcribed verbatim from the proceedings on 3 March 2014 as broadcast on public television.

2 Julien Opening Address (1996) 2; Lucas “Opening address” 1991 University of Hawaii Law Review 351.

3 Perrin "From OJ to McVeigh: The use of argument in opening address" 1999 Emory Law Journal 108.

4 As Marnewick points out, in civil cases there is a greater need for an opening address because the issues usually are more complex and the documentary exhibits are plentiful. Marnewick Litigation Skills for South African Lawyers (2002) 331.

5 Müller et al Prosecuting the Child Sex Offender (2001) 230.

6 Uniform Rule of Court 39(5) as cited in Van Loggerenberg Erasmus Superior Court Practice Volume 2 (2015) D1-519. See also s 150 of the Criminal Procedure Act 51 of 1977. S 150 enables the prosecutor to address the court for the purpose of explaining the charge and indicating the evidence intended to be adduced, but without commenting thereon. This prohibition against commenting upon the evidence is no more restrictive than the rules regarding the opening address in American trial practice. American trial lawyers similarly are prohibited from arguing or otherwise commenting upon the evidence in opening statement. The thesis of this article is that the power of priming lies in the way the trial lawyer sets forth the facts to be proven in an opening address, and not in the trial lawyer commenting on the evidence.

7 Marnewick (2002) 321. By the same token, however, Marnewick argues that "[t]he opening address is a neglected step in the litigation process. Its tactical value is often underestimated and the opportunity to use an opening address to begin the process of persuasion is often not exploited fully," Ibid. 
able to suspend judgment until they have heard all the evidence; that judges somehow are capable of storing away evidence for later digestion as squirrels do nuts. In fact, the exact opposite is true.

Marnewick's assertion does not accord with the courtroom vicissitudes of many a trial lawyer who faces anything but openmindedness from the bench. Rather, their experience is similar to that of John Mortimer's beloved character, Rumpole of the Bailey who, in a case in which the judge took over the questioning of a prosecution witness, whispered to the instructing solicitor: "The judge is suffering from a bad case of premature adjudication." 8 The troubling implication of Marnewick's assertion is that when judges do not keep an open mind it is because they choose not to.

However, it is the premise of this contribution that despite the best efforts of judges to be fair and impartial they cannot keep an open mind throughout the trial. In fact, a fundamental component of human cognition is the automatic evolutionary impulse to "make sense" of and give meaning to the barrage of stimuli to which it attends, even under circumstances in which the information is insufficient to support a definitive conclusion. ${ }^{9}$ A crucial attribute of automatic brain processes is their inescapability; they occur despite a deliberate attempt to bypass or ignore them. ${ }^{10}$ Thus, judges, as are all human beings, are not passive information receivers; they are active information processors. ${ }^{11}$

The purpose in this article is to synthesise the process of legal advocacy in the opening address and research findings in the areas of social cognition, message comprehension and persuasiveness. The goal is to show that beyond its traditional function of "briefly outlining the facts intended to be proved" the opening address is a superlative tool of persuasion - it can predispose the judge favourably to the client's case, pre-emptively affect the judge's reception of the evidence and ultimately affect the eventual outcome of the case.

8 "Rumpole of the Bailey: The old, old story" ITV television broadcast $01 / 19 / 1987$.

9 Grippin \& Peters Learning Theory and Learning Outcomes (1984) 76; Lucas \& McCoy The Winning Edge: Effective Communication and Persuasion Techniques for Lawyers (1993) 115.

10 Devine "Stereotypes and prejudice: Their automatic and controlled components" 1989 Journal of Personality and Social Psychology (J Personality \& Soc Psychol) 6.

11 Linz \& Penrod "Increasing attorney persuasiveness in the courtroom”1984 Law and Psychology Review (L\& Psychol Rev) 17. 


\section{Scientific Foundation for the Persuasive Power of the Opening Address}

\section{Priming}

Research in social cognition suggests that, to a considerable degree, the trial lawyer is able to determine and shape the judge's first impression of a case to the client's advantage. ${ }^{12}$ Primarily, this is done through a process called "priming." Simply put, priming refers to a mental process in which a person's response to later information is influenced by prior information. ${ }^{13}$ Priming creates an impression in a person's mind that then is used to interpret new information. ${ }^{14}$ Priming is powerful because the prime makes certain words, impressions and feelings more accessible to the brain, and thus more likely that the brain will use the activated knowledge category to process subsequent information. ${ }^{15}$

In the 1980s psychologists discovered that exposure to a word causes instantaneous and measurable changes in relation to the ease with which a person can evoke many related words. ${ }^{16}$ For example, if a person recently saw or heard the word EAT, that person would be temporarily more likely to complete the word fragment SO_P as SOUP than as SOAP. Of course SO_P is more likely to become SOAP if that person earlier was exposed to - or primed - with the idea of WASH. ${ }^{17}$

Priming not only is powerful but also is far-reaching. The mental process that occurs when a person is primed with the word EAT is called "associative (or spreading) activation." As do ripples on a pond, ideas that have been primed trigger many other ideas in a speeding cascade of activities in the brain. Thus the word EAT not only primes the idea SOUP, but also a multitude of food-related ideas, such as FORK, HUNGRY, FAT, DIET, COOKIE, etcetera.

This complex series of mental events also is exceedingly coherent. All the elements are connected and each supports and strengthens the other. Words evoke memories; memories evoke emotions; and, in turn, emotions evoke facial expressions and other reactions. All these mental activities occur quickly and simultaneously, "yielding a self-reinforcing pattern of cognitive, emotional, and physical responses that are both diverse and integrated ...". 18

12 Stanchi "The power of priming in legal advocacy: Using the science of first impressions to persuade the reader" 2010-2011 Oregon Law Review (Or L Rev) 306.

13 Higgins "Knowledge activation: Accessibility, applicability, and salience" in Higgins \& Kruglanski (eds) Psychology: Handbook of Basic Principles (1996) 133, 134.

14 See Stanchi 2010-2011 Or L Rev 307.

15 Idem 308, 309.

16 Kahneman Thinking, Fast and Slow (2011) 52.

17 Ibid.

18 Idem 51, 53. 
Therefore, if a prosecutor in the opening address is successful in painting the defendant as a liar, a disreputable person, or a person possessing some other unfavourable trait, the judge is likely to remember the defendant as having all kinds of unpleasant traits. ${ }^{19}$ These kinds of negative impressions are quite strong and will require substantial positive advocacy to overcome. ${ }^{20}$

It is important to note that hardly any of the activated or primed ideas register in consciousness; they arise largely without conscious intention or awareness. ${ }^{21}$ As Daniel Kahneman stresses: "[M]ost of the work of associative thinking is silent, hidden from our conscious selves." 22

Also, research reveals priming to be a strong and consistent reaction. ${ }^{23}$ Not only can peoples' emotions and viewpoints be primed by events of which they are not even aware, but priming can also influence what people see and even how they behave. For example, if a person is primed with the idea of BASEBALL, she is more likely to remember seeing a baseball on a table crowded with many different objects of which a baseball is only one. ${ }^{24}$ The subject will perceive - and remember seeing - the baseball even if catching only the briefest of glimpses of the table. ${ }^{25}$ The baseball will be the most vivid object because, unconsciously, when her mind looked at all the objects on the table it was "searching" for the baseball.

In what has become a classic priming experiment, the psychologist John Bargh and his collaborators at New York University instructed student participants to complete a scrambled-sentence task as part of a language proficiency experiment. ${ }^{26}$ The scrambled-sentence task consisted of a list of five-word sets from which the students were to make grammatical four-word sentences (eg, HE WAS WORRIED SHE ALWAYS). For one group of students, half the scrambled sentences contained words associated with the elderly stereotype, such as FLORIDA, LONELY, GREY, FORGETFUL and WRINKLE. ${ }^{27}$ After completing the task, one of the experimenters surreptitiously recorded the period of time it took each participant to walk down the corridor after leaving the laboratory room. ${ }^{28}$ This measurement was the true purpose of the experiment. As Bargh and his collaborators had hypothesised,

19 Stanchi 2010-2011 Or L Rev 342.

20 Lehrer How We Decide (2009) 81.

21 See generally Bargh "The four horsemen of automaticity" in Weyer \& Skrull (eds) Handbook of Social Cognition (1994) 1-40.

22 Kahneman (2011) 52.

23 Stanchi 2010-2011 Or L Rev 306.

24 Fazio "On the automatic activation of associated evaluations: An overview" 2001 Cognition and Emotion 127-128.

25 Idem 128.

26 Bargh et al "Automaticity of social behavior: Direct effects of trait construct and stereotype activation in action" $1996 \mathrm{~J}$ Personality \& Soc Psychol 230-244.

27 Idem 236-237.

28 Idem 236. 
those participants who had been primed with the elderly stereotype walked down the hallway significantly more slowly than the ones who had not been primed. ${ }^{29}$

The "Florida effect" involved two stages of priming. First, the words related to the elderly stereotype primed thoughts about the state of being old, although the word OLD is never mentioned. Second, these thoughts of old age primed a behaviour - walking slowly - which is associated with old age. The primed thoughts and behaviour occurred without any conscious awareness. ${ }^{30}$ When questioned afterwards none of the students reported noticing that the priming words had a common theme, and they insisted that nothing they did after the experiment could have been influenced by the words they read. Thus, even though the idea of old age never entered their conscious awareness, nevertheless their actions were significantly affected. ${ }^{31}$

In numerous and even more fascinating variations of this priming experiment, researchers in the area of social cognition have established that priming someone with a trait (eg, "rudeness" 32 or "intelligence") 33 or a racial stereotype (eg, "African American") ${ }^{34}$ leads to behaviour which is congruent with the activated constructs.

\section{Priming and First Impressions}

We are conscious of "putting our best foot forward" during a job interview or on a first date because common human experience has taught us that first impressions are powerful and often become lasting impressions. American and English trial lawyers, too, have long been alert to the significance of first impressions. Writing in the American Bar Association Journal in 1948, the legendary barrister, Sir Norman Birkett QC, stated that judges are "never, never likely to forget" the opening address. ${ }^{35}$ "Shaken they may be by cross-examination, by subsequent

29 Idem 237.

30 Kahneman (2011) 53. Gladwell explains the results of the experiment thus: "[T]he scrambled-word test with the "old" primes] was making the big computer in your brain - your adaptive unconscious - think about the state of being old. It didn't inform the rest of your brain with its sudden obsession. But it took all this talk of old age so seriously that by the time you finished and walked down the corridor, you acted old. You walked slowly." Gladwell Blink: The Power of Thinking Without Thinking (2005) 53.

31 Bargh et al $1996 \mathrm{~J}$ Personality \& Soc Psychol 237.

32 See Idem 233-236; Gladwell (2005) 54.

33 Dijksterhuis and van Knippenberg "The relations between perception and behavior, or how to win a game of Trivial Pursuit" 1998 J Personality \& Soc Psychol 865-877. See also Gladwell (2005) 56.

34 Bargh et al $1996 \mathrm{~J}$ Personality \& Soc Psychol 237-240; Teele \& Aronson "Stereotype threat and the intellectual test performance of African Americans" $1995 \mathrm{~J}$ Personality \& Soc Psychol 797-811.

35 Birkett as quoted in Boon Advocacy (1999) 74. See also Marnewick (2002) 321. 
witnesses," he continued, but "that first, clear, incisive impression ... is beyond all price." 36

Our instincts about the salience of first impressions are borne out in a series of studies in cognitive and social psychology that confirm the resilience and tenacity of first impressions. ${ }^{37}$ For example, in one study undergraduate students at the start of a semester formed an impression about their lecturer after watching video clips of as little as two seconds ${ }^{38}$ of the lecturer's non-verbal behaviour in the classroom. ${ }^{39}$ The students' almost instantaneous impressions of a lecturer they had never met based upon the sparsest of information - a two second silent video clip predicted with striking accuracy their end-of-semester evaluations after they had substantial interaction with the lecturer throughout the semester. ${ }^{40}$ Thus, human beings judge swiftly and cling to their snap judgments. ${ }^{41}$

The priming science substantiates the view that the first impression the trial lawyer gives the judge is absolutely critical. Once the judge is primed to form an impression, that impression becomes the lens through which the judge views the events and people involved in the case. ${ }^{42}$ The emotion attached to that first impression shapes the judge's interpretation of the evidence that gradually accumulates throughout the rest of the trial. ${ }^{43}$ This situation is what Eric Morris SC alluded to when he wrote: ${ }^{44}$

"To some extent the judge must be affected by the picture presented in the opening address. He ... may ... have formed a 'view' ... The whole of the subsequent proceeding may then, in the judicial mind, be devoted towards ascertaining whether that "view" or the original picture is to be maintained."

36 Ibid

37 In 2009 neuroscientists mapped those parts of the brain that are activated in the formation of first impressions. fMRI scans of test subjects' brains revealed that primordial neural circuits - the amygdala (regulating emotions) and the posterior cingulate cortex (making financial decisions and assigning values to the outcome of situations) - are activated when people form first impressions of new acquaintances. Although the test subjects were provided with very little information on which to form an opinion, they nevertheless formed first impressions almost instantaneously and automatically, i.e. they could not withhold from doing it. Schiller et al "A neural mechanism of first impressions" 2009 Nature Neuroscience $508-514$.

38 The experimenters varied the length of the video clip for different groups of students from two seconds up to a maximum of ten seconds.

39 Ambady \& Rosenthal "Half a minute: Predicting teacher evaluations from thin slices of nonverbal behaviour and physical attractiveness" 1993 I Personality \& Soc Psychol 438.

40 Ibid. See also Gladwell (2005) 12-13.

41 See Stanchi 2010-2011 Or L Rev 305-306.

42 Idem 333, 335.

43 Kahneman (2011) 82

44 Mullins \& Da Silva Morris Technique in Litigation (2010) 197. 
There is a subtle, but substantial, difference, Morris continues, between "a trial in order to establish which view is correct, and a trial in order to establish the correctness of the view". ${ }^{45}$ The party "who is fortunate to obtain the advantage of that initial reaction will find his task considerably lighter". 46

Significantly, the priming studies also show that the judge will view even irrelevant and ambiguous information through the lens of the primed impression. Indeed, the effects of priming are more pronounced when the later information is ambiguous. In a seminal experiment in 1946 the Gestalt psychologist Solomon Asch presented student participants with short lists of adjectives to describe two fictitious people, and then asked them to write a brief characterisation of the person. ${ }^{47}$ The two lists of adjectives were:

"Alan: intelligent - industrious - impulsive - critical - stubborn - envious

Ben: envious - stubborn - critical - impulsive - industrious - intelligent".

Subjects overwhelmingly viewed Alan much more favourably than Ben. In the participants' minds the initial traits in each list changed the very meaning of the traits that appear later. Stubbornness in an intelligent person may very well be justified and actually invoke respect. However, intelligence in an envious and stubborn person makes her more threatening. The word "stubborn" is ambiguous and will be interpreted in a way that makes it coherent with the context. ${ }^{48}$

This process is called the "halo effect". The halo effect is a cognitive bias that causes a person, when initially forming an impression of another person as friendly, competent or outgoing (or unfriendly, incompetent and introverted, for that matter), to not "weigh" any subsequent information as heavily as the first impression. ${ }^{49}$ This is the case even if subsequent information contradicts the first impression. ${ }^{50}$ The psychologist Abraham Luchins conducted an experiment in which he designed two paragraphs to describe a fictitious character, "Jim", either as outgoing and extroverted, or withdrawn and introverted. ${ }^{51} \mathrm{He}$ then provided these paragraphs to his student subjects and asked them to characterise Jim either as friendly or unfriendly. The students who read the extroverted material first characterised Jim as friendly, whereas those who read the introverted material first rated Jim as being unfriendly. 52

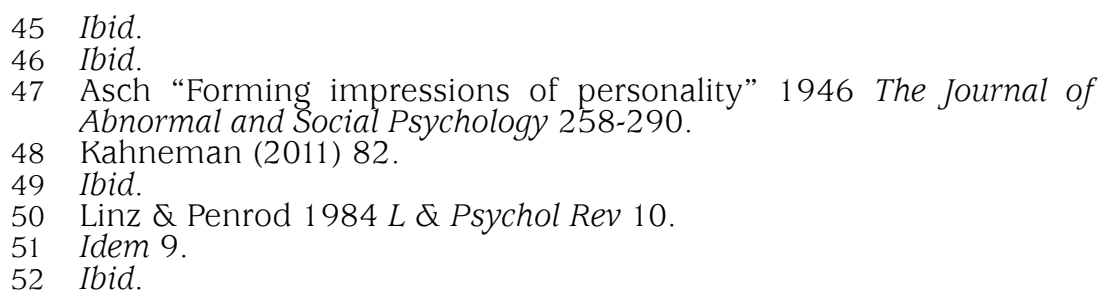


In some instances the halo effect increases the weight of first impressions to such an extent that subsequent information is mostly wasted. ${ }^{53}$ A person's memory may even distort or falsely recall facts about another person or her behaviour that "must have happened" because they are consistent with the first impression. ${ }^{54}$ It should be noted that the listener does not undervalue later information consciously; rather, reliance on first impressions is a mental shortcut (a heuristic) ${ }^{55}$ that the listener takes automatically. ${ }^{56}$

\section{Priming Emotion through Theme and Story}

For far too long the law has clung to the Platonian view that the human mind is torn between the rational and the emotional, and that decisionmaking is best left to the superior rational brain. ${ }^{57}$ As recently as 2008 Brian Garner and the late Justice Antonin Scalia (the former a highlyregarded teacher of legal writing and the latter a United States Supreme Court justice), illustrated the prevalence of this perception when they noted: "Appealing to judges' emotions is misguided ... [P]ersuasion is possible only because all human beings are born with the capacity for logical thought." 58

The notion that emotions are, or should be, severed from decisionmaking conflicts with the results of recent studies in neuroscience. These studies clearly show that emotions intrinsically and intricately are involved in decision-making. Emotion is central to decision-making because in the brain emotional and cognitive-rational pathways are intertwined. ${ }^{59}$ Whether their influence is positive or negative, emotions are always present in decision-making. ${ }^{60}$ Even tangential emotions that are unrelated to the decision at hand can have "a significant impact on judgment and choice". 61

53 Kahneman (2011) 83.

54 Higgins et al "Category accessibility and impression formation" 1977 Journal of Experimental and Social Psychology 141, 142.

55 With regard to cognitive biases and heuristics, see Gravett "The myth of rationality: Cognitive biases and heuristics in judicial decision-making" 2017 SALJ (forthcoming).

56 Linz \& Penrod "Increasing attorney persuasiveness in the courtroom” 1984 L \& Psychol Rev 9.

57 See Gravett 2017 SALJ (forthcoming) and the sources cited there.

58 Scalia \& Garner Making Your Case: The Art of Persuading Judges (2008) 32, 41 .

59 Damasio Descartes' Error: Emotion, Reason and the Human Brain (2005) 34-79; Lowenstein \& Lerner "The role of affect in decision making" in Davidson et al (eds) Handbook of Affective Sciences (2003) 619-620.

60 Lehrer How We Decide (2009) 13-27. For a neuroscientific explanation of the predominance of emotion in decision-making, chapter two which summarises how dopamine neurons facilitate knowledge and decision-making is a good source. Idem 36-41.

61 See Damasio (2005) 34-79; Lerner \& Keltner "Beyond valence: Toward a model of emotion-specific influences on judgment and choice" 2000 Cognition and Emotion 473, 477; Lowenstein \& Lerner (2003) 619. 


\section{Theme}

A trial theme is vital to persuasion because of its connection to emotion. A theme aids the trial lawyer to evoke emotions and impressions in the judge that are favourable to the client. Almost every textbook on trial advocacy emphasises the importance of having an overall theme for the case. ${ }^{62}$ A theme is a memorable word or phrase that embraces the moral essence of the case. It essentially answers the question: Why do fairness and justice mandate a judgment in the client's favour? ${ }^{63}$ Because the objective is to captivate the judge both emotionally and rationally at the outset of the trial, an effective theme compels the judge to embrace the righteousness of the client's cause. ${ }^{64}$

The theme is also critical to memory and retention. It serves as a psychological anchor in memory that assists the judge to integrate and understand the evidence to be lead throughout the remainder of the trial. ${ }^{65}$ When the judge searches her memory to answer a question or make a decision, the theme will guide the search. ${ }^{66}$ The judge is better able to recall the evidence because the theme is helpful in putting the detail into context.

Moreover, a theme helps the judge to "fill in blanks in a story" in that the judge is able to draw inferences consistent with an overarching theme about what "must" have happened, even though some of the details are missing or some information is ambiguous. Inferences and actual events, then, become practically indistinguishable in the judge's memory. 67

62 See, eg, Bergman Trial Advocacy in a Nutshell (1997) 65-67; Gravett The Fundamental Principles of Effective Trial Advocacy (2009) 9-11; Lubet Modern Trial Advocacy: Analysis and Practice (2004) 424-425; Mauet Trial Techniques (2000) 62-64; Mauet Trials: Strategy, Skills, and the New Power of Persuasion (2005) 85; Tigar The Litigator's Art (1999) 80.

63 Bergman (1997) 65; Gravett (2009) 9; Tigar (1999) 80. The most compelling themes state universal truths about life and appeal to the boni mores, civic virtues or common motivations. Themes can be simple but powerful evocative words - "love"; "hate"; "revenge"; fear"; "cheating"; "greed"; "power" - or phrases - "taking responsibility"; "playing by the rules"; "loading the dice"; "profit over safety"; "David versus Goliath". Rhetorical questions make effective themes: "Why did he not wait?"; "Why did she take matters into her own hands?"; "Does a handshake still mean anything?" Mauet (2005) 92. For more examples of themes, refer to the trial advocacy texts in $n 44$.

64 Melili "Succeeding in the opening address" 2005-2006 Am J Trial Advoc 538.

65 Linz \& Penrod 2008 L \& Psychol Rev 6.

66 Idem 5-6.

67 Idem 6. 


\section{Story}

One of the most effective ways to involve the judge in the dispute is to tell a story in the opening address. ${ }^{68}$ Every trial, after all, contains the elements of a story. Because of the trial story's emotional power, the opening address can become powerfully persuasive when the trial lawyer develops the underlying story element of the case. Stories of injustice provoke anger; stories of tragedy provoke sadness. ${ }^{69}$

In emphasising the underlying story-structure of the case, the opening address establishes the core narrative; the perceptual framework that becomes the central interpretive frame into which all subsequent trial persuasion will fit. ${ }^{70}$ The story told in opening address previews, outlines and directs the more developed story that will emerge during the remainder of the trial. ${ }^{71}$ The judge will pay particular attention to the trial story because she remembers the trial in story terms. ${ }^{72}$ Save for a tiny fraction of people, such as those with so-called eidetic and photographic memories, most peoples' brains "are wired to think in story terms". 73 The story form enhances human memory by improving our ability to remember content. ${ }^{74}$ Thus, insofar as the trial lawyer provides the judge with a meaningful, comprehensible story constructed around a memorable theme, the trial lawyer contributes to and facilitates the natural way in which judges reconstruct the facts of the case during deliberation. 75

In research specific to stories in the trial context, these studies show that fact-finders rely extensively on analogy and storytelling to reconstruct the facts of a case in order to arrive at a decision when in deliberation. ${ }^{76}$ In fact, after analysing nearly a hundred trial transcripts, the communication scientist Lance Bennett found that the story is such a powerful organising device that even when the evidence is presented out

68 Rideout "Storytelling, narrative rationality, and legal persuasion" 2008 The Journal of the Legal Writing Institute 54.

69 Stanchi 2010-2011 Or L Rev 313.

70 Snedaker "Storytelling in opening addresss: Framing the argumentation of the trial" 1986-1987 Am J Trial Advoc 16, 17, 44.

71 Idem 44.

72 Braun-Latour \& Zaltman "Memory change: An intimate measure of persuasion” 2006 Journal of Advertising Research 57-72; Pinker How the Mind Works (1997) 37.

73 Braun-Latour \& Zaltman 2006 Journal of Advertising Research 57.

74 Haven Story Proof: The Science Behind the Startling Power of Story (2007) 68.

75 Linz \& Penrod 2008 L \& Psychol Rev 6.

76 Bennett "Rhetorical transformation of evidence in criminal trials: A model of social judgment" 1978 Quarterly Journal of Speech 311. See also Pennington \& Hastie "A cognitive theory of juror decision making: the story model” 1991-1992 Cardozo Law Review 51 9-557. 
of time sequence or elicited through rather disjointed questions and answers the fact-finder rearranges it into a story during deliberation. ${ }^{77}$

\section{Priming Science and the Opening Address}

The potential power of priming and first impressions in the opening address is manifest. The opening address can prime the judge to view the case in a particular way. It is more than a figure of speech to say that the judge "gets a feel" for the case from the opening address. It is literally true. However - and here is where the contribution of the trial lawyer becomes crucial - the "feel" that the judge gets from the opening address is not predestined. At the outset of the trial the judge could have any number of impressions about a set of facts. ${ }^{78}$ Thus the fundamental question is: What can the trial lawyer do to most effectively and ethically integrate the power of priming into crafting a persuasive opening address?

\section{Impact Beginnings}

Because emotions are so central to decision-making, trial lawyers are well-advised to strive to control the judge's emotions about the case and to do so as early as possible. Of the many structural decisions confronting the trial lawyer one of the most important is how to begin. The first paragraph of the opening address constitutes the "beginning of the beginning" of the trial, thus enhancing the potentially powerful impact of the first impression. The priming studies are crystal-clear in their findings that the behaviour that the trial lawyer singles out for mention in the first paragraph of the opening address and the words used to describe that behaviour, contribute to the formation of a first impression that will become the foundation, as well as the driver, of the judge's memory of the events and people involved in the case. ${ }^{79}$

Trial lawyers too often waste the first paragraph of the opening address by adhering to convention in laying out a dry recitation of the background facts of the case. While indubitably it is important to provide the judge with background and context, the trial lawyer can do so and simultaneously prime the judge's first impression of the case. For example, in a case in which a child's mother sued a child protection agency for standing idly by while the child irremediably was injured by his abusive father, the plaintiff can achieve this dual purpose by starting the opening address in the following way: 80

77 Bennett 1978 Quarterly Journal of Speech 311. See also Pennington $\&$ Hastie "Juror decision-making models: The generalization gap" 1981 Psychological Bulletin 246.

78 See Stanchi 2010-2011 Or L Rev 310.

79 Idem 335.

80 Facts adapted from DeShaney $v$ Winnebago Department of Social Services 489 US 189 (1989) as discussed in Stanchi 2010-2011 Or L Rev 335-336. 
"Four-year-old Joshua DeShaney became totally and permanently brain damaged on 8 March 2014, because of the cumulative effects of a continuous process of physical abuse perpetrated by his father and the father's paramour over an extended period. Fourteen months before Joshua's injuries became permanent the local child protection agency began the active phase of its case management of Joshua's physical abuse and neglect. After initially arranging for protective custody to physically protect Joshua from abuse, the agency official returned him to the abusive home of his father. The agency officials did so on their own decision and without court action; and actively followed his case thereafter, dutifully recording in internal documents Joshua's deteriorating situation and their fears for his safety. However, they took no action whatsoever to protect the child."

The opening address quickly and clearly tells the judge who the parties are and why they are before court. Simultaneously, however, it promotes a particular perspective of the facts and sets out to significantly influence the judge's first impression of the case and the parties involved. It depicts Joshua as young and helpless, as well as being permanently injured in a horrific way. It depicts the child-protection agency as being both active in its participation and passively negligent. The opening address paints the caricature of useless bureaucrats who passively observe a terribly dangerous and abusive situation, yet remain mired in inertia except for pointlessly writing reports. ${ }^{81}$

\section{Which Emotions to Prime}

Neuroscientific research suggests that the trial lawyer who ignores the emotional aspects of the case misses an essential opportunity to influence the judge. The trial lawyer should be conscious of how different emotions have different effects on the judge and use this knowledge to the greatest advantage of the client.

On the most basic level positive emotions tend to make people more optimistic, whereas negative emotions tend to make them more pessimistic. ${ }^{82}$ These feelings of optimism or pessimism have a direct bearing on cognitive function. Pessimism, for example, results in a narrowed focus of attention on the part of the perceiver, as well as the motivation to process information more deeply and systematically. ${ }^{83}$ On the other hand, people in positive moods are quicker to decide and tend to focus their attention more broadly and less on specific details. ${ }^{84}$

\footnotetext{
81 See idem 336.

82 Lowenstein \& Lerner (2003) 627.

83 Idem 629. This also makes intuitive sense. Negative emotions usually mean that something is wrong, and this suggests to the brain that more careful and focused attention on the situation is warranted. Stanchi 2010-2011 Or L Rev 318. Studies in negative priming have borne out that people in a negative mood take more time to make a decision, focus on specific details of the decision and remember more negative information. Lowenstein \& Lerner (2003) 629.

84 Ibid.
} 
Plaintiffs and prosecutors of course are the most obvious parties to take advantage of the judge's negative emotions. Usually, these parties want the judge to take action (punish the defendant) or give them something (an award of damages). An opening address that evokes negative feelings through its theme and story can make the judge experience a sense of "wrong" that requires her to take action to remedy it. 85

However, prosecutors and plaintiffs should be judicious in their decision to attempt to evoke negative feelings in the judge. In addition to invoking a sense of "wrong" to be righted, negative feelings may also cause the judge to scrutinise the facts of the case more closely. Thus, engendering negative feelings in the judge might well be appropriate in a case in which the facts preponderantly favour the plaintiff or prosecutor - "cases that [may] benefit from a close look at the 'trees' as opposed to the "forest'". 86 A judge in a positive mood likely will be quicker to reach a decision and will tend to focus their attention more broadly and less on specific details. ${ }^{87}$ A positive mood therefore is more desirable in cases that have "an impressive big picture aspect to them, such as cases that implicate ... policy questions". 88

Beyond simply attempting to evoke generally positive or negative feelings in the judge, trial lawyers should carefully consider which specific positive or negative emotions their trial theme and story elicit. The research illustrates that different emotions cause people to evaluate similar situations differently. For example, once primed for sadness subjects tend to attribute events to situational causes beyond human control as opposed to holding people responsible for events. ${ }^{89}$ In contrast, anger, particularly when connected to feelings that social mores have been violated without consequence, reinforces the perception that negative events are predictable and under human control, which results in the tendency to blame. ${ }^{90}$ A feeling of anger may increase the judge's

85 In his influential work The Sense of Injustice (1949), the philosopher Edmund Cahn points out that the concept of "justice" is vague. It is an abstract ideal not susceptible to precise definition. As a result, an appeal to "justice" is likely to invoke contemplation rather than action. On the other hand, as a concept, "injustice" is immediately recognisable because "feeling wronged" is a common human experience. The concept of "injustice" invokes a sense of unfairness; a wrong to be set right. An appeal to "an injustice suffered" has the power to move a decision-maker to act. Therefore, in constructing trial themes, plaintiffs and prosecutors should avoid abstract concepts - "justice", "freedom", "democracy" - that invite contemplation and philosophical musing. They do not imply a call to action that seeks to remedy a wrong. Gravett (2009) 10.

86 Stanchi 2010-2011 Or L Rev 319.

87 Lowenstein \& Lerner (2003) 629.

88 Stanchi 2010-2011 Or L Rev 319.

89 Keltner et al "Beyond simple pessimism: Effects of sadness or anger on social perception" 1993 Journal of Personality and Social Psychology 741.

90 Idem 742. 
desire to blame individuals (as opposed to random fate) for events, and to overlook mitigating details. ${ }^{91}$

In contrast to plaintiffs and prosecutors, for whom anger can be an effective prime (see the sample opening address above) ${ }^{92}$, generally defendants should strive to avoid priming for anger, because anger likely leads the judge to blame someone, and the defendant is an easy target. But what can the defendant do to counter a dynamic opening address by the prosecutor or plaintiff that told the story of "an evil villain [who] harmed an undeserving victim and escaped without penalty - that is, until justice was placed in the hand of this court who is empowered to correct that injustice"? The defendant faces a seemingly daunting prospect of convincing the judge not to take any action in the case.

The conventional wisdom has been for the defendant to attempt to tell an emotionally neutral story that glosses over unfavourable facts in dry, neutral language. ${ }^{93}$ However, because we know that emotion is an integral and substantial part of decision-making, the choice to tell a "neutral" story essentially cedes emotional power to the other side and forfeits a vital part of the persuasive process. ${ }^{94}$

The scientific research on emotional decision-making, however, does not leave the defendant without recourse. The defendant should attempt to negate a plaintiff's anger prime by telling a positive story that causes the judge to feel more optimistic. If the defendant's story highlights that transgressions have indeed occurred, but that the situation has been quickly and fairly dealt with and/or that the transgressors have been adequately punished, the feelings of anger and injustice that the plaintiff sought to evoke may be neutralised. Such a story with a theme of "all's well that ends well" or "everything's fine now" might be useful to the defendant in a personal injury case (if plaintiff has overcome the injury or the defendant has attempted to remediate the plaintiff's pain and suffering) or a discrimination case (if the employer took prompt remedial action, for example, by promoting the plaintiff or giving her a substantial raise). If the facts do not allow the defendant to tell a story of justice already meted out, the defendant should strive to evoke the emotion of sadness, which can prompt the judge to conclude that there is simply no

91 Goldberg et al "Rage and reason: The psychology of the intuitive prosecutor" 1999 European Journal of Social Psychology 781-782.

92 Although anger is an obvious emotional prime for plaintiffs, sadness might also be effective in some cases. For example, if the plaintiff does not seek to blame the defendant or there is no discernible culprit to blame but instead argues that she is entitled to welfare or some other governmental benefit or aid, sadness is the emotion most likely to be effective. Small \& Lerner "Emotional policy: Personal sadness and anger shape judgments about a welfare case", 2008 Political Psychology 152.

93 See, for example, Fontham et al Persuasive Written and Oral Advocacy in Trial and Appellate Courts (2007) 193-194.

94 Stanchi 2010-2011 Or L Rev 330. 
one to blame. The theme of such a story might be that "there are some wrongs that are simply beyond the law's power to redress."

\section{Memorable and Powerful Stories}

As stated above, the story form enhances peoples' memories and improves their ability to remember content. ${ }^{95}$ However, not all stories are equally memorable or powerful. It is the trial lawyer's task to tell the most emotionally powerful story that the facts allow. The objective is through words to "paint a picture in the mind's eye" 96 of the events from the client's perspective as if the judge herself witnessed the events. ${ }^{97}$ The more detailed and vivid a memory is the greater the emotion attached to it, and the more memorable it is. ${ }^{98}$

A popular misconception among communicators, trial lawyers included, is that adjectives ("large", "minuscule", "gruesome", "heinous", "beautiful") create the best mental pictures. 99 Adjectives, however, tend to convey judgments, which makes them argumentative and therefore less persuasive. Because these words are subjective studies show that a description that contains too many adjectives may be perceived as unreliable by the judge. ${ }^{100}$

Nouns and verbs, on the other hand, have been proven to be the most evocative words. ${ }^{101}$ They do not merely suggest a belief in something, but rather the event, action or person itself. ${ }^{102}$ Thus, the judge immediately can form a strong visual image of that which the trial lawyer is trying to convey.

For example, in the opening address the trial lawyer states: "The accident was terrible" (or "gruesome", "horrendous", "deadly", "awful"). The use of these, although vivid, descriptors is a subjective judgment. ${ }^{103}$ A description of the accident as "terrible" could mean different things to

95 Haven (2007) 68.

96 Morrill Trial Diplomacy (1972) 22.

97 Melili 2005-2006 Am J Trial Advoc 534; Powell "Opening address: The art of storytelling” 2001-2002 Stestson Law Review 90-91. Powell comments: "It is essential that that trial lawyer recognize that what is taking place is only slightly different from that which occurs around the campfire, in the movie theater, at a child's bedside ... it is a form of communication as old as humankind itself ... Yet, its objective is the same: to communicate to an audience the occurrence of some event, and to do so in a way that will affect the audience to the desired result." Powell 2001-2002 Stestson Law Review 90.

98 Singer "Memory, emotion and psychotherapy: Maximizing the positive functions of self-defining memories" in Uttl et al (eds) Memory and Emotion: Interdisciplinary Perspectives (2006) 111, 217.

99 Lubet "Persuasion at trial" 1997 Am J Trial Advoc 334.

100 Voss "The science of persuasion: An exploration of advocacy and the science behind the art of persuasion in the courtroom" 2005

101 Ibid Law and Psychology Review 307.

102 Lubet 1997 Am J Trial Advoc 335; Voss 2005 L \& Psychol Rev 308. 
different people. It conveys a qualitative judgment, but not the factual basis of the judgment. ${ }^{104}$ By contrast, consider the difference in persuasive power when the trial lawyer describes the accident using predominantly nouns and verbs:

"The roof of the car was smashed in on top of the driver. Blood dripped down the side of the driver's door, splattered on the grass and soaked into the ground. The plunge down the ravine ripped off the wheels and the bonnet of the car."

These noun and verb combinations (roof/smashed; grass/splattered; ground/soaked; wheels and bonnet/ripped) offer a more descriptive and reliable - and thus more persuasive - description of the accident. ${ }^{105}$

Mark Twain said: "The difference between the almost right word and the right word is really a large matter - 'tis the difference between the lightning bug and the lightning". 106 The trial lawyer uses words in the same way that the artist uses paint. In drawing a "virtual picture" of events that is memorable and compelling, the trial lawyer should be mindful of evocation - word choice. Words convey images, so the right word must be chosen for maximum effect. Referring to the client as "the plaintiff" conveys a different image than calling her "Mrs Thomas". To state that the victim "died" conveys a different image than saying the victim was "killed" or "gunned down". Describing the scene of a robbery as the "house" conveys a different image than referring to it as a "home" (the former clinically connotes a structure, whereas the latter invokes images of privacy, warmth and intimacy). ${ }^{107}$

In a series of studies subjects were shown a film of a motor vehicle collision and asked to estimate the speed of the vehicle upon impact. The researchers used different verbs to describe the collision, and found that subjects' estimates of the speed varied depending on the researchers' choice of verb. When the subjects were told that the vehicle "crashed" into the wall, their estimates of the speed upon impact were significantly higher than when they were told the vehicle "made contact" with the wall. ${ }^{108}$

\section{Is the Defendant at an Insurmountable Disadvantage?}

The research on priming and first impressions might create the sense that the plaintiff and prosecutor, who generally have the first opportunity to present an opening address, have an insurmountable advantage over the defendant, who may present an opening address only at the close of the prosecution or plaintiff's case. While the advantage is

103 Underwood "Logic and the common law trial" 1994 Am J Trial Advoc 187.

104 See Gravett (2009) 13.

105 Voss 2005 L \& Psychol Rev 308.

106 As quoted in Bainton The Art of Authorship (1890) 87-88.

107 Gravett (2009) 11.

108 Saks \& Hastie Social Psychology in Court (1978) 115. 
indisputable, ${ }^{109}$ social psychological research suggests that it is not insurmountable. Indeed, it might be possible for the defendant to counteract the dominant effect of first impressions in a number of ways.

Studies show that people are more persuaded by an argument if they have had the opportunity to hear a few opposing arguments. When people are aware that there are two sides to an issue (precisely the situation in which the judge finds herself), a one-sided presentation is seen as a biased communication, and thus less trustworthy and less persuasive. ${ }^{110}$

Psychological reactance is another reason why people are reluctant completely to accept the conclusions of a one-sided communication. Reactance is aroused when pressure to adopt a certain position in a twosided issue is perceived by the listener as a threat to her freedom to decide the issue herself. ${ }^{111}$ A way for the listener to restore a feeling of freedom is to adopt a position contradictory to the one-sided position advocated. ${ }^{112}$

An experiment, premised upon the prosecution's summation in a bigamy trial illustrates how reactance is formed. The experimenters presented subjects with either one-sided or two-sided arguments for conviction. In one condition the subjects were told that the case was not "open and shut", and that both the prosecution and defense had presented credible witnesses. In the other condition the subjects read only the prosecution's arguments. The results demonstrated that the least effective argument was the one-sided argument when the factfinder knew that there were two sides. ${ }^{113}$

American trial lawyers and advocacy scholars are very aware of the principle of "primacy" when they discuss the importance of the opening address. ${ }^{114}$ Simply put, primacy is a psychological principle that holds that what is perceived first is most likely to be remembered, believed and

109 One can argue that the advantage is probably deserved, because it is generally the prosecutor and the plaintiff who bear the burden of proof.

110 Chu "Prior familiarity, perceived bias, and one-sided versus twosided communications" 1967 Journal of Experimental and Social Psychology 243.

111 Jones \& Brehm "Persuasiveness of one- and two-sided communications as a function of awareness that there are two sides" 1970 Journal of Personality and Social Psychology 47.

112 Sensing \& Brehm "Attitude change from an implied threat to attitudinal freedom" 1968 Journal of Personality and Social Psychology 324; Worchel \& Brehm "Direct and implied social restoration of freedom" 1971 Journal of Personality and Social Psychology 294.

113 Ibid.

114 See, eg, Riley "The opening address: Winning at the outset" 1979 1980 Am J Trial Advoc 225; Smith "The opening address as a tool of persuasion" 1979-1980 Am J Trial Advoc 261; Lubet "The opening moment" 1993 South Texas Law Review 123. 
embraced, and least likely to be discarded. ${ }^{115}$ However, the research on primacy and persuasion seems to suggest that while people commonly use the first bits of information they receive to form an impression they are not always persuaded by the first statement or argument they hear. In fact, there is evidence to support the principle that what is presented last, not first, will be more persuasive. This possibility is referred to as the "recency effect". 16 Therefore, it might behoove the defendant always to present an opening address that sets forth her theory of the case. ${ }^{117}$

Moreover, the recency effect becomes more greatly amplified the longer the delay is between the first and second presentation. ${ }^{118}$ Thus, the longer the prosecutor or plaintiff takes to conclude her case the more persuasive the defendant's opening address seems to become.

\section{The Ethics of Priming}

Morris describes the opening address as the trial lawyer's "first opportunity to subtly poison the judge's mind" with the essence of the client's case. ${ }^{119}$ Although the sentiment is to be applauded, the use of the word "poison" is unfortunate. It may suggest that there is something inherently nefarious or underhand or even unethical in utilising priming science to enhance the persuasive power of the opening address.

Priming certainly is not innately unethical, but trial lawyers should be cautious in its use. The fact that priming is a largely unconscious reaction is the source of its power. ${ }^{120}$ However, this means that trial lawyers should be particularly mindful of ethics. It is possible to prime someone to make a wrong or biased decision. ${ }^{121}$ Priming is effective because of the caches of "knowledge categories" in our memories. Thus, to the

115 Baum "The plaintiff's approach in opening address" in Holmes (ed) Persuasion: The Key to Success in Trial (1978) 18. Colley explains the principle of primacy thus: "[W]e tend to believe most deeply that which we first heard, and whichever side of an issue is presented first will have a greater influence on opinion than an equally strong but later presentation of the opposite side." Colley "Friendly persuasion: Gaining attention, comprehension, and acceptance in court" 1981 (August) Trial 46.

116 Kristi \& Klein "Finishing strong: Recency effects in juror judgments" 2005 Basic and Applied Social Psychology 56-57.

117 Contra Morris who states: "[I]t will only be rarely that the defendant will find it necessary to take advantage of the right conferred by rule 39(7) and 'briefly outline the case'. When there is something in particular to be brought under the attention of the court then the right should be utlised. Otherwise not" Mullins \& Da Silva (2010) 204.

118 Miller \& Campbell "Recency and primacy in persuasion as a function of the timing of speeches and measurements" 1959 Abnormal and Social Psychology 1.

119 Mullins \& Da Silva (2010) 199.

120 Devine 1989 J Personality \& Soc Psychol 6.

121 Higgins et al 1977 Journal of Experimental and Social Psychology 141,142 . 
extent that we carry prejudices, stereotypes or other biases as part of the knowledge categories in our brains - and we all do - it is possible to tap into that information. ${ }^{122}$ For example, in one study an "averaged size Black man" sitting on a park bench during his lunch hour was described as "lazy." What test subjects remembered, however, was a "big, healthy" Black man "sprawling idly" on a park bench and "doing nothing all day". All of the fabricated "remembered" impressions were primed by the word "lazy". ${ }^{123}$ In another study subjects were primed with words suggesting race (eg, black, negro, slavery) and racial stereotypes (eg, lazy, poor, aggressive). Researchers concluded that subjects who had been primed to think of a character described in racially neutral terms as "Black" automatically and unconsciously attributed "hostility" to the character because the latter is a stereotypical characteristic associated with that racial category. ${ }^{124}$

These results counsel trial lawyers to be scrupulous in their use of priming. Because priming can tap into our unconscious stereotypes with particular tenacity and power, trial lawyers should make every effort to use this technique honestly and ethically. A dishonest prime that plays on stereotypes or group-based bias is unethical and immoral.

\section{Conclusion}

Studies of priming effects have yielded discoveries that are quite disturbing. The results from these experiments threaten our self-image as conscious and autonomous authors of our judgments and our choices. ${ }^{125}$ They suggest that what we think of as free will largely is an illusion. However, as the Nobel-laureate Daniel Kahneman remarks with regard to these priming studies: ${ }^{126}$

"[D]isbelief is not an option. The results are not made up, nor are they statistical flukes. You have no choice but to accept that the major conclusions of these studies are true. More important, you must accept that they are true about you."

The idea that a South African judge - or a judge anywhere in the world for that matter - is able to refrain from forming an opinion until all the evidence has been heard is aspirational rather than realistic. The time has come to reject the "open mind" fallacy and accept that the conscious

122 Devine 1989 J Personality \& Soc Psychol 6. On implicit racial bias specifically in the legal context, see Gravett "The myth of objectivity: Implicit racial bias and the law" (parts 1 and 2) 2017 PELJ (forthcoming).

123 Higgins et al 1977 Journal of Experimental and Social Psychology 141,142

124 Devine 1989 J Personality \& Soc Psychol 11-12. Even subjects who did not exhibit significant amounts of explicit racial prejudice as measured by the Modern Racism Scale could still be primed to elicit prejudicial responses.

125 Kahneman (2011) 55.

126 Idem 57. 
mind is not the source or origin of human behaviour. Instead, priming unconsciously activates impulses to act, and the role of the consciousness is as gatekeeper and sense-maker after the fact. ${ }^{127}$ Conscious processes kick in only after a behavioural impulse has occurred in the brain - ie, a prime first generates an impulse unconsciously and then consciousness claims and experiences it as its own. ${ }^{128}$

Sound psychological theory, buttressed by common experience, suggests that the opening address potentially is of great significance in affecting the ultimate judgment in a case. Trial lawyers should accept that judges, at the very least, form preliminary judgments or working hypotheses after the opening address, which they use throughout the trial. Priming in the opening address works not only to influence the judge's feel for the "big picture" of the case but also to actuate the construct of a framework in the judge's mind that colours the receipt and processing of the evidence which follows. Judges are more likely to hear details that they expect to hear based upon the opening address, and to fail to notice or actively to disregard inconsistent information.

Priming, it should be said, is not a magic bullet that can turn a bad case into a good one, but, to a significant degree, it can influence the judge's view of the facts or the law, and create an enduring impression of the characters involved in the case. It can create vivid and lasting impressions that stay with the judge long after the informational detail has been forgotten. ${ }^{129}$

Trial lawyers should embrace and use social psychological research to learn and refine the skill at the heart of courtroom lawyering: how to persuade effectively and ethically. Confronted with the robust research on priming, I hope that South African trial lawyers in future at least pause before waiving the opportunity to present an opening address and dismissing it as a "waste of time". Given the potential impact of the opening address on the outcome of the trial, it is a crucial opportunity to persuade.

127 Bargh \& Morsella "The unconscious mind" 2008 Perspectives on Psychological Science 77; Bargh et al $1996 \mathrm{~J}$ Personality \& Soc Psychol 230-231.

128 Bargh \& Morsella 2008 Perspectives on Psychological Science 77.

129 Stanchi 2010-2011 Or L Rev 345. 